\title{
Identification of diverse germplasm lines for agronomic traits in a chickpea (Cicer arietinum L.) core collection for use in crop improvement
}

\author{
H.D. Upadhyaya *, S.L. Dwivedi, C.L.L. Gowda, S. Singh \\ Genetic Resources, Crop Improvement, International Crops Research Institute for the Semi-Arid Tropics (ICRISAT), \\ Patancheru 502324, Andhra Pradesh, India
}

Received 19 May 2006; received in revised form 21 August 2006; accepted 22 August 2006

\begin{abstract}
Utilization of exotic and diverse germplasm is needed to enhance the genetic diversity of cultivars. Genetically diverse lines provide ample opportunity to create favorable gene combinations, and the probability of producing a unique genotype increases in proportion to the number of genes by which the parents differ. Representative core collections (10\% of the entire collection) have been suggested as a means to identify useful parents for crop improvement programs. The chickpea core collection (1956 accessions) was evaluated for 14 agronomic traits in two seasons to identify diverse agronomically superior chickpea germplasm. Season (year) and genotypic effects were significant for 13 of the 14 traits, while genotype $\times$ season effect was significant for 8 traits. The desi, kabuli, and intermediate type chickpeas differed significantly for days to maturity, basal secondary branches, pods per plant, seed yield, and 100-seed weight. In comparison to controls, 12 accessions flowered early, 15 produced greater seed yield, and 29 had greater 100-seed weight. Based on days to 50\% flowering, pods per plant, seed yield, and 100-seed weight, 19 desi, 15 kabuli and 5 intermediate type chickpea germplasm lines originating from 10 countries were selected. The selected desi accessions produced 8.5\% more seed yield and had 32\% larger seeds than the control cultivar Annigeri while the selected kabuli accessions yielded at par with control L 550 but had $84 \%$ larger seeds. The 39 selected accessions and two control cultivars (Annigeri and L 550) were grouped by their first five principal components (PCs) into three clusters. Cluster 1 consisted of early maturing large-seeded kabuli types, cluster 2 early and late maturing desi types, and cluster 3 late maturing intermediate and kabuli types. Clusters 2 and 3 accessions had small to medium sized seeds. These accessions can be used in chickpea breeding programs to develop high yielding desi and kabuli cultivars with a broad genetic base.
\end{abstract}

(C) 2006 Elsevier B.V. All rights reserved.

Keywords: Chickpea; Desi; Diversity; Evaluation; Germplasm; Intermediate; Kabuli

\section{Introduction}

Chickpea (Cicer arietinum L.) is one of the most important grain-legume crops in the world, with the Asia region contributing most to the production, 7.67 million tonnes $(\mathrm{Mt})$ of the $10.38 \mathrm{Mt}$ of the world chickpea production (FAO, 2004). The major chickpea producing countries in Asia are India, Turkey, Pakistan, and Iran. Africa and North Central America contribute about 3-4\% of the world chickpea production, with Ethiopia in Africa and Mexico in North Central America being the main producers of chickpea in these regions. Large variations in chickpea yield are reported: from $0.35 \mathrm{t} \mathrm{ha}^{-1}$ in Iran to $1.60 \mathrm{tha}^{-1}$ in Mexico. Chickpea

\footnotetext{
* Corresponding author. Tel.: +91 4030713333 ; fax: +9140 30713074/30713075.

E-mail address: h.upadhyaya@cgiar.org (H.D. Upadhyaya).
}

productivity between 1965/1974 and 1995/2004 increased consistently in India and Mexico while it declined in Turkey, Pakistan, and Iran (FAO, 1965-2004; http://www.faostat.fao.org/site/408/default.aspx). Several biotic and abiotic stresses, besides lack of adapted varieties, contribute to the fluctuations in chickpea yield. Ascochyta blight [Ascochyta rabiei (Pass.) Labr.], botrytis gray mold (Botrytis cinerea Pers. ex Fr.), fusarium wilt [Fusarium oxysporum Schlechtend.emend W.C. Snyder. \& H.N. Hans. f. sp. ciceris (Padwick) W.C. Snyder \& H.N. Hans.], fusarium root rot [Fusarium solani (Mart.) Sacc. f. sp. eumartii (C. Carpenter) W.C. Snyder \& H.N. Hans.], dry root rot [Rhizoctonia bataticola (Taubenhaus) E.J. Butler], nematodes (Heterodera ciceri Vovlos, Greco \& Di Vito and Meloidogyne spp.), pod borer (Helicoverpa armigera Hübner), and leaf miner (Liriomyza cicerina Rondani) among the biotic stresses and drought, salinity, and high and low temperature, among the abiotic stresses, are the major constraints to chickpea 
productivity (Upadhyaya et al., 2006). Worldwide these stresses together cause yield losses worth US\$ 2559 million annually, of which it is estimated that US\$ 1185 million (46\%) could be recovered by developing improved chickpea cultivars with multiple resistances to biotic and abiotic stresses (ICRISAT, 1992).

Utilization of exotic germplasm in breeding programs is needed to enhance the productivity and diversity of cultivars. However, breeders in general make use of only their own working collection, which they often recycle in breeding programs (Duvick, 1995; Cox et al., 1988). Extensive use of few and closely related germplasm/breeding lines in crop improvement could result in vulnerability of newly developed cultivars to pests and diseases (Duvick, 1984; Cox et al., 1986). For example, low genetic diversity led to the epidemic of southern corn leaf blight [Bipolaris maydis (Nisik) Shoemaker] in corn (Holley and Goodman, 1989). Lack of genetic diversity also led to a plateau in genetic improvements of yield in common bean (McClean et al., 1993). Diverse genetic backgrounds among parental lines provide the allelic variation necessary to create favorable new gene combinations, and the probability of producing unique genotypes increases in proportion to the number of genes by which the parents differ. To enhance utilization of chickpea genetic resources in breeding, Upadhyaya et al. (2001) developed a chickpea core collection of 1956 accessions representing between $84 \%$ and $100 \%$ of the variation range of the entire collection for plant height, days to maturity, numbers of pods per plant and seeds per pod, seed yield, and 100seed weight. Multi-environmental evaluation of such core collections has been suggested as a method to identify diverse germplasm with beneficial traits (Upadhyaya et al., 2001). The main objective of this study was to evaluate the chickpea core collection for agronomic traits to identify diverse germplasm for enhancing the genetic potential of chickpea cultivars.

\section{Materials and methods}

One thousand nine hundred and fifty-six chickpea core collection accessions, consisting of 1465 desi (74.9\%), 433
(22.1\%) kabuli, and 58 (3.0\%) intermediate types, were grown in single row plots in an augmented design with three control cultivars (Annigeri, G 130, and L 550) widely grown in India (Saxena and Singh, 1987). Annigeri (ICC 4918) is an early maturing high yielding desi cultivar and G130 (ICC 4948) is late maturing high yielding desi cultivar. L 550 (ICC 4973) is a high yielding medium duration kabuli cultivar. One of the controls was repeated after every nine-test entries. The experiment was conducted under high input conditions (100 $\mathrm{kg} \mathrm{ha}^{-1}$ diammonium phosphate as basal dose and full protection against diseases and insect pests) in vertisol field at ICRISAT Center Patancheru, India during the 1999/2000 and 2000/2001 postrainy seasons. Data of the 1999/2000 season has been used to study diversity in this core collection (Upadhyaya et al., 2002) and to develop the mini core collection (Upadhyaya and Ortiz, 2001). Solarization was done to control soil-borne diseases (Katan et al., 1987). Each plot consisted of a single row of $4 \mathrm{~m}$ with spacing of $60 \mathrm{~cm}$ between rows and $10 \mathrm{~cm}$ between plants within a row. The experiment received two irrigations $(5 \mathrm{~cm}$ each), one at flowering and another at podding stage, in addition to one to support germination. Preemergence herbicide, Glyphosate (Roundup) at $8 \mathrm{~kg}$ in 6001 water ha ${ }^{-1}$ was applied 1 month before sowing to control weeds. Six sprays of Acephate (Starthane) at $1 \mathrm{~kg}$ in 3251 water ha ${ }^{-1}$ and two sprays of Lannate (Methomyl) at $1 \mathrm{~kg}$ in 3251 water ha ${ }^{-1}$ were applied to control legume pod borer (H. armigera). IBPGR, ICRISAT, and ICARDA (1993) chickpea descriptors were used to record observations on days to $50 \%$ flowering, flowering duration, plant height and width $(\mathrm{cm})$, days to maturity, and number of basal primary branches, apical primary branches, basal secondary branches, apical secondary branches, and tertiary branches, pods per plant, seeds per pod, seed yield $\left(\mathrm{kg} \mathrm{ha}^{-1}\right)$, and 100-seed weight $(\mathrm{g})$. Five traits, days to flowering and maturity, flowering duration, 100seed weight, and seed yield were recorded on plot basis, and the remaining nine traits on representative five plants (Table 1).

Statistical analysis was performed following the Residual Maximum Likelihood (REML) on GENSTAT 6.1 for both years separately and on the combined data. Variance components due

Table 1

Chickpea descriptors used for evaluating core collection at ICRISAT Patancheru, 1999/2000 and 2000/2001 seasons

\begin{tabular}{|c|c|}
\hline Trait & Descriptor \\
\hline Days to $50 \%$ flowering (no.) & Number of days from sowing or first irrigation to the stage when $50 \%$ of plants in a plot have begun flowering \\
\hline Flowering duration (no.) & Number of days between $50 \%$ flowering and end of flowering in $50 \%$ plants of a plot \\
\hline Plant height $(\mathrm{cm})$ & Average canopy height $(\mathrm{cm})$ of five representative plants at the end of flowering \\
\hline Plant width $(\mathrm{cm})$ & Average spread $(\mathrm{cm})$ of five representative plants at the end of flowering \\
\hline Basal primary branches (no.) & Average number of basal primary branches of five representative plants \\
\hline Apical primary branches (no.) & Average number of apical primary branches of five representative plants \\
\hline Basal secondary branches (no) & Average number of basal secondary branches of five representative plants \\
\hline Apical secondary branches (no.) & Average number of apical secondary branches of five representative plants \\
\hline Tertiary branches (no.) & Average number of tertiary branches of five representative plants \\
\hline Days to maturity (no.) & Number of days from sowing or first irrigation to the stage when $90 \%$ of pods have matured or turned yellow \\
\hline Pods per plant (no.) & Average number of pods of five representative plants \\
\hline Seeds per pod (no.) & Average of 10 pods each from five representative plants \\
\hline 100-Seed weight $(\mathrm{g})$ & 100-Seed weight $(\mathrm{g})$ measured at $10 \%$ (air dry) moisture content \\
\hline Seed yield $\left(\mathrm{kg} \mathrm{ha}^{-1}\right)$ & Seed yield per plot $\left(\mathrm{kg} \mathrm{ha}^{-1}\right)$ \\
\hline Seed shape & Seed shape $(1=$ angular (desi type), $2=$ owl's head (kabuli type), and $3=$ pea shaped (intermediate type) \\
\hline
\end{tabular}


to genotype $\left(\delta_{\mathrm{g}}^{2}\right)$, genotype $\times$ environment (years) $\left(\delta_{\mathrm{ge}}^{2}\right)$, residual $\left(\delta_{\mathrm{e}}^{2}\right)$ and their standard errors were estimated. In the combined analysis, seasons were considered as fixed and genotypes as random. Best linear unbiased predictors (BLUPs) were obtained for each trait. The means, ranges, and variances of all the traits were separately calculated for desi, kabuli, and intermediate groups. For individual traits, the means of these three groups were compared using the Newman-Keuls procedure (Newman, 1939; Keuls, 1952). Homogeneity of variances was tested using Levene's test (Levene, 1960). Principal component analysis (PCA) was performed for 14 traits. Subtracting from each observation the mean value of the trait, and subsequently dividing by its respective standard deviation, gave standardized observations of traits with average 0 and standard deviation of 1 or less. These standardized values were used to perform the PCA using GENSTAT 6.1. Correlation coefficients between the first 5 principal component scores and the 14 agronomic traits were calculated to determine the relationship between principal components and traits. Cluster analysis using scores of first five PCs was performed following the method of Ward (1963).

\section{Results and discussion}

REML analysis indicated that the variance component due to genotype was nonsignificant for three traits (basal secondary branches, tertiary branches, and seeds per pod) in 1999/2000 and for five traits (basal and apical primary branches, basal and apical secondary branches, and tertiary branches) in 2000/2001 (data not given). However, in the combined analysis the genotype variance was significant for 13 of the 14 observed traits (days to $50 \%$ flowering, flowering duration, plant height and width, days to maturity, basal primary and secondary branches, apical secondary branches, tertiary branches, pods per plant, seeds per pod, seed yield, and 100-seed weight) (Table 2). This indicated that differences existed between the core collection accessions for these traits. Season's effect was significant for all observed traits except for 100-seed weight (data not given). Genoty- pe $\times$ season (environment) interaction was significant for days to $50 \%$ flowering, flowering duration, plant $50 \%$ flowering, days to maturity, apical primary branches, tertiary branches, pods per plant, and 100-seed weight indicating differential performance of core collection genotypes in the two seasons. The reason for the occurrence of $\mathrm{G} \times \mathrm{E}$ interaction in this study possibly could be due to differential response of genotypes to variation in climatic and soil factors in two seasons that the core collection was evaluated. For example, minimum temperature was lower by $2{ }^{\circ} \mathrm{C}$ when the chickpea crop was in seedling and vegetative/pod formation stage in 1999/2000 than in 2000/2001 crop season. The maximum temperature and solar radiation in the two seasons remained similar, however, both solar radiation $\left(19.34 \mathrm{MJ} \mathrm{m}^{-2}\right.$ ) and temperature $33.6^{\circ} \mathrm{C}$ ) were higher in February 2001 than during the same period in 2000 (solar radiation $16.69 \mathrm{MJ} \mathrm{m}^{-2}$ and temperature $31.2{ }^{\circ} \mathrm{C}$ ) thus possibly forcing the crop to mature early in the 2000/2001 crop season, which might have adversely affected the expression of reproductive traits.

Based on seed shape, three types of chickpea-desi, kabuli, and intermediate are recognized. Desi types are angular-shaped, small-seeded, and dark-colored; kabuli types are owl headshaped, large-seeded, and cream-colored; and the intermediate types have pea-shaped seeds. The estimates of variance due to genotype in desi type chickpea accessions were significant for three traits (apical primary branches, pods per plant, and seeds per pod) in 1999/2000 and for five traits (days to 50\% flowering, days to maturity, apical primary branches, pods per plant, and seeds per pod) in 2000/2001, while in combined analysis, except for tertiary branches, estimates of variance due to genotype were significant for all traits (data not given). In the kabuli group, the estimates of genotypic variance were significant for three traits (plant width, basal primary branches, and 100-seed weight) in $1999 / 2000$ and for one trait (100-seed weight) in 2000/2001 but in combined analysis, except for basal and apical primary branches and tertiary branches, estimates of genotypic variance were significant for all traits (data not given). In the intermediate group, variance due to genotype was significant for plant height

Table 2

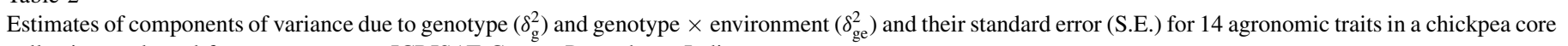
collection evaluated for two seasons at ICRISAT Center, Patancheru, India

\begin{tabular}{|c|c|c|c|c|}
\hline Trait & $\delta_{\mathrm{g}}^{2}$ & S.E. & $\delta_{\mathrm{ge}}^{2}$ & S.E. \\
\hline Day to $50 \%$ flowering (no.) & $62.04^{* *}$ & 2.206 & $7.07^{* *}$ & 0.611 \\
\hline Flowering duration (no.) & $18.45^{* *}$ & 0.859 & $6.12^{* *}$ & 0.750 \\
\hline Plant height $(\mathrm{cm})$ & $30.42^{* *}$ & 1.560 & $12.10^{* *}$ & 1.630 \\
\hline Plant width $(\mathrm{cm})$ & $7.18^{* *}$ & 0.790 & 2.45 & 1.520 \\
\hline Days to maturity (no.) & $10.62^{* *}$ & 0.466 & $1.16^{* *}$ & 0.396 \\
\hline Basal primary branches (no.) & $0.03^{* *}$ & 0.009 & 0.002 & 0.0064 \\
\hline Apical primary branches (no.) & 0.05 & 0.033 & $0.13^{*}$ & 0.065 \\
\hline Basal secondary branches (no.) & $0.19^{* *}$ & 0.036 & 0.01 & 0.023 \\
\hline Apical secondary branches (no.) & $0.24^{* *}$ & 0.064 & 0.16 & 0.085 \\
\hline Tertiary branches (no.) & $0.07^{*}$ & 0.031 & $0.10^{*}$ & 0.049 \\
\hline Pods per plant (no.) & $191.70^{* *}$ & 20.100 & $71.3^{*}$ & 34.5 \\
\hline Seeds per pod (no.) & $0.02^{* *}$ & 0.002 & 0.0006 & 0.00104 \\
\hline Seed yield $\left(\mathrm{kg} \mathrm{ha}^{-1}\right)$ & $125,422^{* *}$ & 7866 & 7115 & 4676 \\
\hline 100 -Seed weight $(\mathrm{g})$ & $57.10^{* * *}$ & 1.845 & $0.33^{* *}$ & 0.100 \\
\hline
\end{tabular}

\footnotetext{
* Significant at $P=0.05$.

** Significant at $P=0.01$.
} 
Table 3

Range of variation for agronomic traits among accessions belonging to desi, kabuli, and intermediate types in chickpea core evaluated for two seasons at ICRISAT Center, Patancheru, India

\begin{tabular}{|c|c|c|c|c|}
\hline Trait & Entire core collection & Desi & Kabuli & Intermediate \\
\hline Flowering duration (no.) & $25.3-55.1$ & $25.4-53.3$ & $25.3-55.1$ & $30.2-45.7$ \\
\hline Plant height $(\mathrm{cm})$ & $27.9-68.8$ & $27.9-63.2$ & $33.2-66.6$ & $37.1-68.8$ \\
\hline Plant width (cm) & $41.3-53.5$ & $41.3-53.5$ & $44.5-53.4$ & $44.0-52.3$ \\
\hline Days to maturity (no.) & $106.9-122.0$ & $106.9-122.0$ & $109.4-122.0$ & $110.5-119.4$ \\
\hline Basal primary branches (no.) & $2.5-2.8$ & $2.5-2.8$ & $2.5-2.8$ & $2.5-2.7$ \\
\hline Apical primary branches (no.) & $1.5-1.7$ & $1.5-1.7$ & $1.5-1.7$ & $1.5-1.6$ \\
\hline Tertiary branches (no.) & $1.5-2.0$ & $1.6-1.9$ & $1.5-1.9$ & $1.6-2.0$ \\
\hline Pods per plant (no.) & $42.8-102.2$ & $45.3-102.2$ & $42.8-87.4$ & $49.2-91.3$ \\
\hline Seeds per pod (no.) & $1.1-1.6$ & $1.1-1.6$ & $1.1-1.5$ & $1.2-1.5$ \\
\hline Seed yield $\left(\mathrm{kg} \mathrm{ha}^{-1}\right)$ & $975.5-2554.2$ & $991.2-2554.2$ & $975.5-2351.0$ & $980.4-2192.3$ \\
\hline 100-Seed weight (g) & $8.5-63.0$ & $8.5-36.8$ & $9.9-63.0$ & $9.3-52.2$ \\
\hline
\end{tabular}

in 1999/2000 and for plant height and tertiary branches in 2000/ 2001 while in the combined analysis, except for four traits (basal and apical primary branches and basal and apical secondary branches), it was significant for all observed traits (data not given). Table 3 gives the range of variation for 14 agronomic traits among accessions belonging to the desi, kabuli, and intermediate groups of chickpeas in this core collection. The range for days to $50 \%$ flowering, flowering duration, and $100-$ seed weight was wider among kabuli chickpeas while the range for plant height and width, days to maturity, pods per plant, seeds per pod, and seed yield was greater among desi chickpeas. For intermediate types, the range was closer to that for desi types for days to 50\% flowering, flowering duration, and number of apical secondary branches while it was closer to that for kabuli types for plant height and plant width, days to maturity, number of basal secondary branches, pods per plant, seeds per pod, seed yield, and 100-seed weight. The range of variation among desi types represented from 53\% (100-seed weight) to $100 \%$ (plant width, basal secondary branches, apical primary branches, days to maturity, and seeds per pod) of the ranges recorded for the entire core collection. Among kabuli types the variation ranged from $61 \%$ (apical secondary branches) to $100 \%$ (days to $50 \%$ flowering and flowering duration) of that observed for the entire core collection while for intermediate types it ranged from 52\% (flowering duration) to $91 \%$ (tertiary branches). There were significant differences among the means of desi, kabuli and intermediate types (Table 4). The three types chickpeas differed significantly for days to maturity, basal secondary branches, pods per plant, seed yield, and 100-seed weight. The desi and kabuli chickpeas differed significantly for days to $50 \%$ flowering, plant height and width, and for seeds per pod. In comparison to desi, the kabuli accessions were later in maturity, taller with a broader plant canopy (as measured by plant width), possessed less number of pods per plant and seeds pod, had lower seed yields but had greater 100-seed weight. The intermediate types differed from kabuli types for days to $50 \%$ flowering, plant width, apical secondary branches and tertiary branches. There were no differences among the means of the three types of chickpeas for flowering duration, basal primary branches, and apical primary branches.

Table 4

Mean for agronomic traits among accessions belonging to desi, kabuli, and intermediate types in chickpea core evaluated for two seasons at ICRISAT Center, Patancheru, India

\begin{tabular}{|c|c|c|c|c|}
\hline Trait & Entire core collection & $\operatorname{Desi}^{\mathrm{a}}$ & Kabuli $^{\mathrm{a}}$ & Intermediate $^{\mathrm{a}}$ \\
\hline Day to $50 \%$ flowering (no.) & 61.47 & $60.35 \mathrm{~b}$ & $65.18 \mathrm{a}$ & $62.24 \mathrm{~b}$ \\
\hline Flowering duration (no.) & 38.41 & $38.47 \mathrm{a}$ & $38.23 \mathrm{a}$ & $38.16 \mathrm{a}$ \\
\hline Plant height $(\mathrm{cm})$ & 44.50 & $43.76 \mathrm{~b}$ & $46.71 \mathrm{a}$ & $46.56 \mathrm{a}$ \\
\hline Plant width $(\mathrm{cm})$ & 47.51 & $47.32 \mathrm{~b}$ & $48.17 \mathrm{a}$ & $47.55 \mathrm{~b}$ \\
\hline Days to maturity (no.) & 114.03 & $113.33 \mathrm{c}$ & $116.31 \mathrm{a}$ & $114.76 \mathrm{~b}$ \\
\hline Basal primary branches (no.) & 2.63 & $2.63 \mathrm{a}$ & $2.64 \mathrm{a}$ & $2.62 \mathrm{a}$ \\
\hline Apical primary branches (no.) & 1.56 & $1.56 \mathrm{a}$ & $1.56 \mathrm{a}$ & $1.56 \mathrm{a}$ \\
\hline Basal secondary branches (no.) & 3.50 & $3.51 \mathrm{~b}$ & $3.48 \mathrm{c}$ & $3.53 \mathrm{a}$ \\
\hline Apical secondary branches (no.) & 5.39 & $5.39 \mathrm{~b}$ & $5.38 \mathrm{~b}$ & $5.43 \mathrm{a}$ \\
\hline Tertiary branches (no.) & 1.72 & $1.72 \mathrm{a}$ & $1.72 \mathrm{a}$ & $1.74 \mathrm{~b}$ \\
\hline Pods per plant (no.) & 64.20 & $66.26 \mathrm{a}$ & $57.22 \mathrm{c}$ & $62.10 \mathrm{~b}$ \\
\hline Seeds per pod (no.) & 1.28 & $1.29 \mathrm{a}$ & $1.23 \mathrm{~b}$ & $1.24 \mathrm{~b}$ \\
\hline Seed yield $\left(\mathrm{kg} \mathrm{ha}^{-1}\right)$ & 1819.10 & $1883.10 \mathrm{a}$ & $1617.68 \mathrm{c}$ & $1707.01 \mathrm{~b}$ \\
\hline 100 -Seed weight $(\mathrm{g})$ & 17.45 & $14.86 \mathrm{c}$ & $25.99 \mathrm{a}$ & $19.12 \mathrm{~b}$ \\
\hline
\end{tabular}

\footnotetext{
${ }^{\text {a }}$ Differences between means of desi, kabuli, and intermediate type chickpea were tested by Newman-Keuls test. Means followed by the same letter are not significantly different at $P=0.05$.
} 
Days to 50\% flowering, pods per plant, 100-seed weight, and seed yield are important agronomic traits. Based on significant superiority or performance similar to the controls (Annigeri for desi and L 550 for kabuli and intermediate types) for the above mentioned traits, we identified 19 desi, 15 kabuli, and 5 intermediate chickpea accessions originating from 10 countries that can be used in breeding programs to enhance the genetic potential of chickpea (Table 5). For example, among desi type,
6 accessions flowered early, 8 produced greater seed yield, and 13 had larger 100-seed weight than control Annigeri. Among kabuli types, 5 accessions flowered early, 6 produced greater seed yield, and 15 had larger 100-seed weight than control L 550. In intermediate type chickpeas, one accession each flowered early, produced greater seed yield, and had greater 100 -seed weight than L 550. Few accessions showed superiority over controls for a number of traits among the three

Table 5

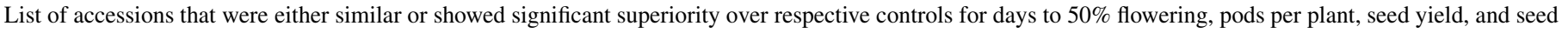
weight for use in genetic enhancement of chickpea

\begin{tabular}{|c|c|c|c|c|c|c|c|c|}
\hline $\mathrm{ICC}$ & $\begin{array}{l}\text { Origin } \\
\text { country }\end{array}$ & $\begin{array}{l}\text { Year } \\
\text { received/collected }\end{array}$ & $\begin{array}{l}\text { Biological } \\
\text { status }\end{array}$ & $\begin{array}{l}\text { Days } \\
\text { to } 50 \% \\
\text { flowering (no.) }\end{array}$ & $\begin{array}{l}\text { Plant } \\
\text { height } \\
(\mathrm{cm})\end{array}$ & $\begin{array}{l}\text { Pods per } \\
\text { plant (no.) }\end{array}$ & $\begin{array}{l}\text { Seed yield } \\
\left(\mathrm{kg} \mathrm{ha}^{-1}\right)\end{array}$ & $\begin{array}{l}\text { 100-Seed } \\
\text { weight } \\
(\mathrm{g})\end{array}$ \\
\hline \multicolumn{9}{|l|}{ Desi } \\
\hline 1230 & India & 1973 & Landrace & 54 & 43.9 & 74.2 & 2455.8 & 20.6 \\
\hline 1692 & India & 1973 & Landrace & 56 & 46.6 & 63.3 & 2504.6 & 20.3 \\
\hline 1836 & India & 1973 & Landrace & 68 & 47.8 & 69.1 & 2395.3 & 31.0 \\
\hline 5449 & India & 1973 & Landrace & 54 & 42.7 & 71.6 & 2403.7 & 21.0 \\
\hline 5697 & India & 1973 & Landrace & 50 & 42.5 & 63.2 & 2080.7 & 36.8 \\
\hline 5970 & India & 1973 & Landrace & 50 & 45.0 & 73.0 & 2168.6 & 24.8 \\
\hline 6122 & India & 1973 & Landrace & 40 & 43.3 & 64.0 & 1832.2 & 34.6 \\
\hline 8324 & India & 1974 & Landrace & 46 & 39.7 & 72.0 & 2251.8 & 21.7 \\
\hline 8332 & India & 1974 & Breeding material & 52 & 46.8 & 64.1 & 2554.2 & 18.7 \\
\hline 8348 & India & 1974 & Landrace & 44 & 46.9 & 61.5 & 2471.7 & 34.9 \\
\hline 8474 & Spain & 1974 & Landrace & 43 & 46.5 & 53.5 & 2036.8 & 34.6 \\
\hline 10819 & India & 1976 & Landrace & 48 & 44.5 & 57.1 & 2041.3 & 33.8 \\
\hline 11152 & India & 1978 & Landrace & 42 & 38.5 & 65.3 & 2130.6 & 20.9 \\
\hline 12197 & India & 1981 & Breeding material & 44 & 41.1 & 72.0 & 2178.3 & 28.6 \\
\hline 13124 & India & 1984 & Landrace & 48 & 40.0 & 53.5 & 2188.4 & 33.9 \\
\hline 13200 & Iran & 1984 & Landrace & 50 & 46.6 & 57.2 & 2027.6 & 36.7 \\
\hline 14230 & India & 1985 & Landrace & 49 & 48.5 & 55.1 & 2166.8 & 33.7 \\
\hline 16862 & India & 1994 & Landrace & 45 & 41.7 & 74.0 & 2288.0 & 25.2 \\
\hline 16934 & India & 1994 & Landrace & 48 & 40.5 & 72.0 & 2212.9 & 23.1 \\
\hline \multicolumn{9}{|l|}{ Kabuli } \\
\hline 3410 & Iran & 1973 & Landrace & 54 & 42.9 & 65.0 & 2138.7 & 21.8 \\
\hline 5644 & India & 1973 & Landrace & 61 & 46.3 & 60.3 & 2138.8 & 23.3 \\
\hline 6160 & Syria & 1974 & Landrace & 59 & 42.2 & 66.0 & 1996.1 & 40.5 \\
\hline 6239 & Tunisia & 1974 & Landrace & 69 & 43.7 & 52.5 & 2029.6 & 33.0 \\
\hline 6246 & Tunisia & 1974 & Landrace & 63 & 40.9 & 68.0 & 1898.0 & 21.8 \\
\hline 7200 & Egypt & 1974 & Breeding material & 62 & 43.9 & 58.9 & 2171.4 & 21.5 \\
\hline 8042 & Iran & 1974 & Landrace & 59 & 50.9 & 55.4 & 2075.8 & 30.8 \\
\hline 8155 & USA & 1974 & Unknown & 41 & 38.5 & 45.2 & 1233.4 & 60.2 \\
\hline 10755 & Turkey & 1976 & Landrace & 61 & 45.7 & 57.7 & 2014.7 & 31.4 \\
\hline 10783 & Turkey & 1976 & Landrace & 61 & 45.3 & 60.0 & 2167.2 & 35.6 \\
\hline 11904 & Morocco & 1981 & Advanced cultivar & 63 & 48.8 & 62.1 & 2117.7 & 25.0 \\
\hline 12034 & Mexico & 1981 & Advanced cultivar & 36 & 40.6 & 48.4 & 1382.4 & 59.1 \\
\hline 14190 & India & 1985 & Landrace & 43 & 46.6 & 48.9 & 1297.1 & 63.0 \\
\hline 14203 & Mexico & 1985 & Landrace & 46 & 42.3 & 50.8 & 1632.4 & 57.3 \\
\hline 15763 & Syria & 1989 & Landrace & 59 & 44.0 & 69.0 & 1886.2 & 26.0 \\
\hline \multicolumn{9}{|l|}{ Intermediate } \\
\hline 4871 & India & 1973 & Landrace & 51 & 42.6 & 61.6 & 2018.6 & 28.3 \\
\hline 5899 & India & 1973 & Landrace & 59 & 45.2 & 84.4 & 2192.3 & 26.1 \\
\hline 7574 & Morocco & 1974 & Landrace & 71 & 59.4 & 56.7 & 1790.1 & 30.6 \\
\hline 8350 & India & 1974 & Landrace & 61 & 46.3 & 64.8 & 2017.6 & 27.2 \\
\hline 16345 & India & 1991 & Breeding material & 64 & 49.8 & 49.2 & 1283.5 & 52.2 \\
\hline \multicolumn{9}{|l|}{ Control } \\
\hline Annigeri (desi) & India & 1973 & Released cultivar & 50 & 41.6 & 70.0 & 2057.5 & 21.3 \\
\hline L 550 (kabuli) & India & 1973 & Released cultivar & 63 & 45.5 & 64.0 & 1858.2 & 19.9 \\
\hline GM & & & & 61.42 & 44.50 & 64.25 & 1821.13 & 17.46 \\
\hline S.E. \pm & & & & 1.89 & 2.38 & 5.94 & 68.52 & 0.53 \\
\hline $\mathrm{CV} \%$ & & & & 4.00 & 10.85 & 38.77 & 24.08 & 6.21 \\
\hline
\end{tabular}


chickpea seed types. For example, ICC 8348, ICC 12197 and ICC 16862 in desi type, and ICC 3410 in kabuli type were early in flowering, produced greater seed yield and had higher 100seed weight than controls. ICC 5899 belonging to the intermediate type was better than controls for pods per plant, seed yield, and 100-seed weight. These accessions were not evaluated for reaction to ascochyta blight in this study, however, information available on nine accessions in the database, indicated that only ICC 1692, a desi landrace from India was moderately resistant (score of 4 on a 1-9 scale, where $1=$ immune and $9=$ highly susceptible) and ranked second for seed yield (Table 5). Accessions having high seed yield and greater 100-seed weight than controls were ICC 1836 among desi types and ICC 5644, ICC 7200, ICC 8042, ICC 10783, and ICC 11904 among kabuli types. The most desirable accessions possessing early maturity and greater 100-seed weight than controls, were ICC 6122, ICC 8474, and ICC 12197 in desi; ICC 8155, ICC 12034, ICC 14190, and ICC 14203 among kabuli types; and ICC 4871 among intermediate types. These accessions are good sources of new germplasm that should be exploited in breeding programs to derive high yielding cultivars in chickpea.

The principal component analysis (PCA) was used to provide a reduced dimension model that would indicate measured differences among the 39 most diverse accessions identified in this study (Fig. 1). The PC 1, which is the most important component, accounted for $33.0 \%$ variation and separated accessions on five traits: days to $50 \%$ flowering, flowering duration, days to maturity, plant width, and apical secondary branches. Similarly, PC2 separated accessions based on plant height, apical primary branches, and pods per plant; PC3 on tertiary branches and seed yield; PC4 on seeds per pod; and PC5 on basal secondary branches. This was also evident from high correlations of the first five PCs with these different traits. Thus PC1 was highly correlated with days to $50 \%$ flowering (-0.829), flowering duration (0.796), days to maturity $(-0.683)$, apical secondary branches $(-0.668)$, and plant width $(-0.664)$; PC2 with pods per plant $(0.666)$, plant height $(-0.630)$, and apical primary branches (0.596); PC3 with seed yield (0.710), and 100-seed weight (g) (-0.430); PC4 with seeds per pod (0.866); and PC5 with basal secondary branches (0.337). A hierarchical cluster analysis conducted on the first five principal components accounted for $80.5 \%$ variation and formed three distinct clusters: cluster 1 represented exclusively the kabuli types that flower early with exceptionally high 100-seed weight (57-63 g); cluster 2 represented desi types with a mixed group of early and late flowering types having 100-seed weight between 21 and $37 \mathrm{~g}$; and cluster 3, that also included Annigeri and L 550, represented late flowering kabuli and intermediate types with 100 -seed weights between 19 and $40 \mathrm{~g}$. For breeding high yielding early maturing kabuli types with large 100-seed weights, ICC 8155, ICC 12034, ICC 14190, and ICC 14203 included in cluster 1 could be crossed with some of the highest yielding kabuli accessions (ICC 3410, ICC 5644, ICC 7200, and ICC 10783) and desi accessions (ICC 1230, ICC 1692, ICC 8332, and ICC 8348). The selected intercrossing between the desi and kabuli types might result in superior lines that combine the beneficial/desirable traits from both groups.

Crop genetic resources will be the main contributing factor to the most of future progress in developing new cultivars. However, the greatest challenge before the genebank curators/ plant breeders is to identify useful genetic variation from the existing large germplasm collections, especially for traits of economic importance that require replicated multilocational evaluation. Establishing core collections was suggested as a means to overcome the size-induced low use of germplasm in applied breeding (Frankel, 1984; Frankel and Brown, 1984). The limited evaluation of a chickpea core collection in this study provided an opportunity to identify accessions superior in performance and diverse from control cultivars, thus providing new sources of variation for agronomic traits that can be

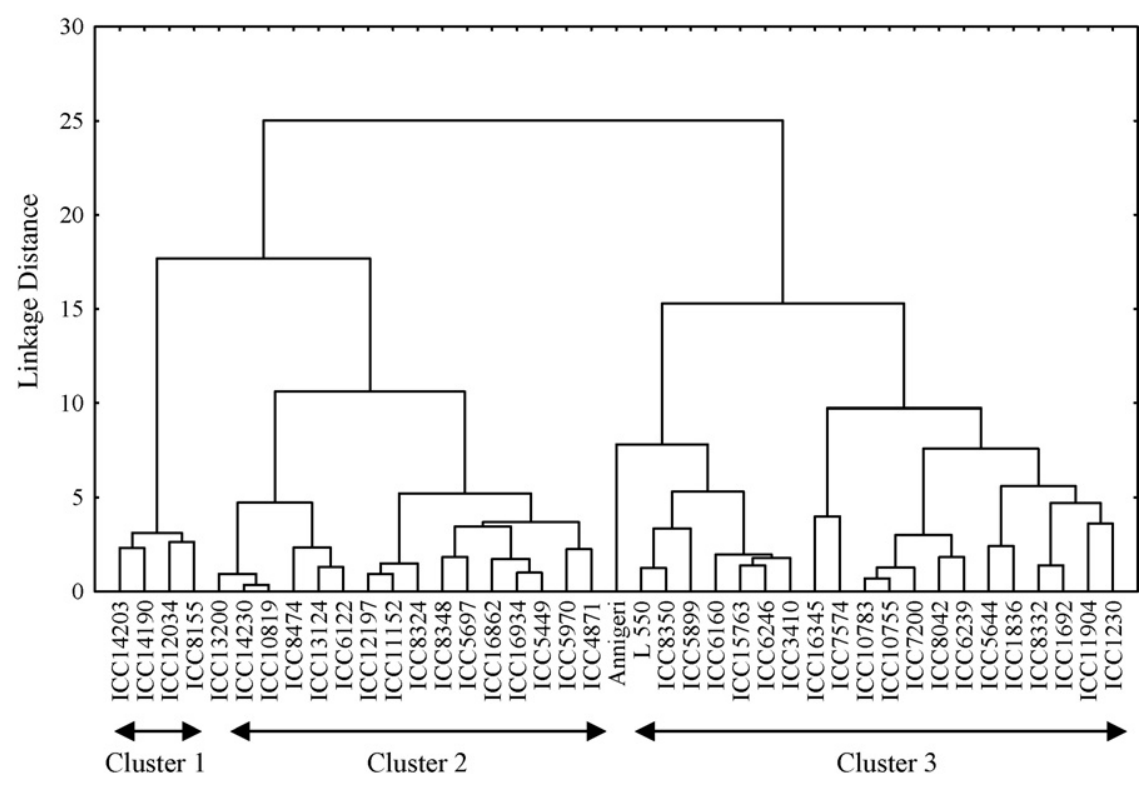

Fig. 1. Dendogram of 41 chickpea accessions based on scores of first five principal components. 
exploited to enhance the genetic potential of desi and kabuli chickpeas. It is expected that when such diverse lines are involved in breeding programs, as a result of reshuffling of the alleles due to recombination, there will be better chances for the appearance of transgressive segregants with beneficial traits that can be selected to extract high yielding lines with desirable trait combinations. Since these lines have good agronomic value (Table 5), their use will not adversely affect the speed of improvement programs resulting from epistatic effects. It is important to consider genetic background and agronomic performance while selecting exotic germplasm lines for inclusion in applied plant improvement programs, as it will be useful in predicting their behavior in hybrid combinations with adapted genotypes (Upadhyaya et al., 2005). If the diversity between lines is less, it is more likely that additive gene effects will play a primary role in the inheritance of quantitative traits (Isleib and Wynne, 1983). However, as the diversity between parents increases, dominance and epistatic effects have more significant roles (Halward and Wynne, 1991) that would have implications in choosing an appropriate selection strategy in a self-pollinated crop such as chickpea.

\section{References}

Cox, T.S., Murphy, J.P., Rodgers, D.M., 1986. Changes in genetic diversity in red and winter wheat regions of the United States. Proc. Natl. Acad. Sci. 83, 5583-5586.

Cox, T.S., Murphy, J.P., Goodman, M., 1988. The contribution of exotic germplasm to American agriculture. In: Kloppenburg, J.R. (Ed.), Seeds and Sovereignty: The Use and Control of Plant Genetic Resources. Duke University Press, Durham, NC, p. 114.

Duvick, D.N., 1984. Genetic diversity in major farm crops on the farm and in reserve. Econ. Bot. 38, 161-178.

Duvick, D., 1995. Security and long-term prospects for conservation of genetic resources. Res. Domes. Intl. Agribusiness Manage. 11, 33-45.

FAO, 2004. FAO Production Year Book. FAO http://www.faostat.fao.org/

FAO, 1965-2004. http://www.faostat.fao.org/site/408/default.aspx.

Frankel, O.H., 1984. Genetic perspective of germplasm conservation. In: Arber, W., Llimensee, K., Peacock, W.J., Starlinger, P. (Eds.), Genetic Manipulations: Impact on Man and Society. Cambridge University press, Cambridge, pp. $161-170$.

Frankel, O.H., Brown, A.H.D., 1984. Current plant genetic resources-a critical appraisal. In: Chopra, V.L., Joshi, B.C., Sharma, R.P., Bansal, H.C. (Eds.), Genetics: New Frontiers, vol. 4. Oxford and IBH Publ. Co., New Delhi, pp. $1-13$.
Halward, T.M., Wynne, J.C., 1991. Generation means analysis for productivity in two diverse peanut crosses. Theor. Appl. Genet. 82, 784-792.

Holley, R.N., Goodman, M.M., 1989. New sources of resistance to southern corn leaf blight from tropical hybrid maize derivatives. Plant Dis. 73, 562 564.

IBPGR, ICRISAT, ICARDA, 1993. Descriptors for chickpea (Cicer arietinum L.). International Board for Plant Genetic Resources, Rome, Italy; International Crops Research Institute for the Semi-Arid Tropics, Patancheru, India and International Center for Agriculture Research in the Dry Areas, Aleppo, Syria.

ICRISAT, 1992. Medium Term Plan 1994-1998. Volume 1 Main Report (Appendix B-Yield loss tables) (Limited circulation).

Isleib, T.G., Wynne, J.C., 1983. Heterosis in testcrosses of 27 exotic peanut cultivars. Crop Sci. 23, 832-841.

Katan, J., Grinstein, A., Greenberger, A., Yarden, O., DeVay, J.E., 1987. First decade (1976-1986) of soil solarization (solar heating) — a chronological bibliography. Phytoparasitica 15, 229-255.

Keuls, M., 1952. The use of the 'Studentized range' in connection with an analysis of variance. Euphytica 1, 112-122.

Levene, H., 1960. Robust tests for equality of variances. In: Olkin, I. (Ed.), Contributions to Probability and Statistics: Essays in Honor of Harold Hotelling. Stanford University Press, Stanford, pp. 278-292.

McClean, P.E., Myers, J.R., Hammond, J.J., 1993. Coefficient of parentage and cluster analysis of North American dry bean cultivars. Crop Sci. 33, 190197.

Newman, D., 1939. The distribution of range in samples from a normal population expressed in terms of an independent estimate of standard deviation. Biometrika 31, 20-30.

Saxena, M.C., Singh, K.B., 1987. Chickpea breeding. In: Saxena, M.C., Singh, K.B. (Eds.), The Chickpea. CAB International, Wallingford, UK, pp. 127162.

Upadhyaya, H.D., Bramel, P.J., Singh, S., 2001. Development of chickpea core subset using geographic distribution and quantitative traits. Crop Sci. 41, 206-210.

Upadhyaya, H.D., Furman, B.J., Dwivedi, S.L., Udupa, S.M., Gowda, C.L.L., Baum, M., Crouch, J.H., Buhariwalla, H.K., Singh, S., 2006. Development of a composite collection for mining germplasm possessing allelic variation for beneficial traits in chickpea. Plant Genet. Resour. 4, 13-19.

Upadhyaya, H.D., Mallikarjuna Swamy, B.P., Kenchana Goudar, P.V., Kullaiswamy, B.Y., Singh, S., 2005. Identification of diverse groundnut germplasm through multienvironment evaluation of a core collection for Asia. Field Crops Res. 93, 293-299.

Upadhyaya, H.D., Ortiz, R., 2001. A mini core subset for capturing diversity and promoting utilization of chickpea genetic resources in crop improvement. Theor. Appl. Genet. 102, 1292-1298.

Upadhyaya, H.D., Ortiz, R., Bramel, P.J., Singh, S., 2002. Phenotypic diversity for morphological and agronomic characteristics in chickpea core collection. Euphytica 123, 333-342.

Ward, J., 1963. Hierarchical grouping to optimize an objective function. J. Am. Stat. Assoc. 38, 236-244. 